\title{
Predictors of Macro and Microvascular Complication in Type 2 Diabetes Mellitus Patients at Dr. Moewardi Hospital, Surakarta
}

\author{
Handoko'), Setyo Sri Rahardjo²), Bhisma Murti1) \\ ${ }^{1)}$ Masters Program in Public Health, Universitas Sebelas Maret \\ 2)Faculty of Medicine, Universitas Sebelas Maret
}

\begin{abstract}
Background: Type 2 Diabetes Mellitus (Type 2 DM) is one of the major causes of morbidity and mortality worldwide. Morbidity and mortality due to diabetes are associated with the development of various microvascular complications (retinopathy, nephropathy, and neuropathy) and macrovascular complications (coronary heart disease, stroke, and peripheral vascular disease). This study aimed to examine the determinants of biopsychosocial macro and microvascular complications in patients with type $2 \mathrm{DM}$ at Dr. Moewardi Surakarta.

Subjects and Method: This was an analytic observational with a case-control design. The study was conducted at Dr. Moewardi, Surakarta, Central Java, from January to March 2018. A sample of 75 Type 2 DM cases with complication and 75 Type 2 DM cases without complication was selected for this study by fixed disease sampling. The dependent variables were macro and microvascular complications. The independent variables were body mass index (BMI), blood pressure, quality of life, depression, duration of disease, physical activity, diet, medication adherence, health financing, and routine blood sample. Clinical data were taken from medical record. The data of other variables were collected by a set of pre-tested questionnaire. Logistic regression was employed for data analysis.

Results: The risk of macro and microvascular complications in type $2 \mathrm{DM}$ patients increased with high $\mathrm{BMI}(\mathrm{OR}=22.00 ; 95 \% \mathrm{CI}=7.50$ to $64.52, \mathrm{p}<0.001)$, poor quality of life $(\mathrm{OR}=7.06$; $\mathrm{CI} 95 \%=$ 3.51 to $14.16, \mathrm{p}<0.001)$, depression $(\mathrm{OR}=3.30 ; 95 \% \mathrm{CI}=1.39$ to $7.79, \mathrm{p}=0.007)$, longer duration of disease $(\mathrm{OR}=9.71 ; 95 \% \mathrm{CI}=2.79$ to $33.71, \mathrm{p}<0.001)$, lack of physical activity $(\mathrm{OR}=8.16 ; 95 \% \mathrm{CI}=$ 1.23 to $53.93, \mathrm{p}=0.029)$, poor $\operatorname{diet}(\mathrm{OR}=3.58$; $95 \% \mathrm{CI}=1.39$ to $9.18, \mathrm{p}=0.008)$, poor medication adherence $(\mathrm{OR}=4.54 ; 95 \% \mathrm{CI}=1.71$ to $12.05, \mathrm{p}=0.002)$, and irregular blood sample control $(\mathrm{OR}=$ $5.80 ; 95 \% \mathrm{CI}=1.97$ to $14.65, \mathrm{p}=0.001$ ).

Conclusion: The risk of macro and microvascular complications in patients with type $2 \mathrm{DM}$ is determined by BMI, quality of life, depression, duration of disease, physical activity, diet, medication adherence, and blood sample control.
\end{abstract}

Keywords: biopsychosocial, macrovascular, microvascular, complications, type 2 DM

\section{Correspondence:}

Handoko. Masters Program in Public Health, Universitas Sebelas Maret, Jl. Ir. Sutami 36 A, Surakarta, Indonesia. Email: handhira83@yahoo.co.id. Mobile: +6285225591917.

\section{BACKGROUND}

Type 2 diabetes mellitus (DM) is one of the major causes of morbidity and mortality worldwide (Cohen et al., 2017). Diabetes became one of the greatest global health emergencies in the 21st century. Every year, more and more people are living with this condition, which can result in life-altering complications. In addition to the 415 million adults estimated to have diabetes today, there are 318 million adults with impaired glucose tolerance, which puts them at high risk for future illness (IDF, 2015).

Diabetes is associated with the development of various microvascular complications (retinopathy, nephropathy and neuropathy) and macrovascular complications (coronary heart disease, stroke and peri- 
Indonesian Journal of Medicine (2018), 3(1): 1-13 https://doi.org/10.26911/theijmed.2018.03.01.01

pheral vascular disease). In addition to vascular complications, diabetes is also associated with other comorbidities, including increased risk of malignancy, osteoporosis, depression, sleep disorders and reproductive disorders (Ma, 2016).

Based on the International Diabetes Federation (IDF) data estimation, the DM case in 2015 in the world is 415 millions with 5 millions deaths cases and is estimated to reach 642 millions by 2040. The incidence of DM is 1 in 11 adults by 2015 and estimated in 2040 to 1 in 10 adults. Indonesia in 2015 ranks 7th highest in the world that is 10 million people and estimated the number will increase to 16.2 million people in 2040 and will be ranked the 6th highest in the world (IDF, 2015).

Diabetes ranks second from the main priority of non-infectious disease control in Central Java at 18.33\% (Central Java Provincial Health Office, 2015). Based on Surakarta District health profile, cases of diabetes are into the top 10 patterns of disease. In 2014, data in Community Health Center show that the cases of DM type 2 were about 17,696 and 11,349 data from the hospital. If the prevalence is calculated then a number of 6,105 per 100,000 population was obtained. The cases found in 2013 were 4,500 per 100,000 population (Surakarta City Health Office, 2014). Based on the preliminary study results in Dr. Moewardi hospital, Surakarta shhow that the visit of DM type 2 patients in polyclinic outpatient in January 2016 until October 2017 were about 15,099 people, while those undergoing hospitalization were for about 3114 people. The visit of patients with type 2 diabetes mellitus was the second largest after hypertension disease in polyclinic disease in Dr. Moewardi hospital Surakarta.

The high prevalence of macrovascular and microvascular complications in type 2 diabetes mellitus is an urgent problem that must be solved by using an approach model capable of assessing various related factors. This study employed a biopsychosocial model approach to assess the determinants based on causation and risk factors for macrovascular and microvascular complications biologically, psychologically and socially. The biopsychosocial model of health is a model used to describe biological, psychological and social factors, since the determination of disease determinants based on biological causes alone is not sufficient to explain the occurrence of disease processes in the body (Murti, 2016). Based on the description, the researchers are interested to examine the determinants of biopsychosocial macrovascular and microvascular complications in patients with type 2 diabetes in Dr. Moewardi Hospital, Surakarta.

\section{SUBJECTS AND METHOD \\ 1. Study Design}

This was an analytic observational study with a case control design. The study was conducted at Dr. Moewardi hospital, Surakarta, Central Java, from January to March 2018.

\section{Population and Sample}

The source population in this study was patient of type $2 \mathrm{DM}$ who underwent treatment at Dr. Moewardi hospital, Surakarta. The case population was patient of type 2 DM patient with macrovascular and microvascular complication who underwent treatment at Dr. Moewardi hospital both in outpatient and inpatient for about 150 samples. Meanwhile, the control population was a type 2 DM patient without macrovascular and microvascular complications who underwent the treatment of Dr. Moewardi for about 75 samples. The sampling used fixed disease sampling technique.

\section{Study variable}

The dependent variables were macrovascular and microvascular complications in 
type 2 DM patients. The independent variables were Body Mass Index (IMT), blood pressure, quality of life, depression, duration of disease, physical activity, diet, medication adherence, health financing and blood samples (haematology).

\section{Operational definition of variables}

Macrovascular complication of type 2 diabetes was defined as complications involving larger arterial blood vessels, leading to atherosclerosis which includes coronary heart disease, stroke and gangrene in the leg, whereas microvascular complications are complications of small blood vessels that include diabetic retinopathy, diabetic nephropathy and diabetic neuropathy.

Body mass index (BMI) was defined as a simple assessment to monitor the nutritional status of adults, particularly those associated with underweight and overweight which are calculated as weight in kilograms divided by the square of height in meters $\left(\mathrm{kg} / \mathrm{m}^{2}\right)$.

Blood pressure was defined as the pressure measured at a pulse expressed in millimeters of mercury $(\mathrm{mmHg})$. The data were collected by questionnaire. The measurement scale was continuous.

Quality of life was defined as the perception of individuals viewed from the cultural context, the value system in which they live, the relationship of pleasure, and their attention that includes physical, psychological, social, and environmental health as measured by using the WHO-Qol BREF questionnaire with 26 question items (Derakhshanpour et al., 2015). The data were collected by questionnaire. The measurement scale was continous, but for the purpose of data analysis, it was transformed into dichotomous. Coded 1 for bad quality of life, coded o for good quality of life.

Depression was defined as subject's statement of loss of interest or pleasure, guilt or inferiority, disturbed sleep or loss of appetite, low energy and decreased concentration as measured by the Beck Depression Inventory-II (BDI-II) questionnaire (Zhang et al., 2015; Derakhshanpour et al., 2015). The measurement scale was continous, but for the purpose of data analysis, it was transformed into dichotomous. Coded 1 for depressed, coded o for not depressed.

The duration of the disease was defined as the subject's statement about the duration/ time of the illness that has been suffered by the subject from the time of diagnosis by the physician until the study was conducted.

The physical activity was defined as the subject's statement of behavior in running an activity or physical exercises consisting of time spent walking outdoors, time spent in sports practice, and contributions to domestic work (Al-Kaabi et al., 2009). The measurement scale was continous, but for the purpose of data analysis, it was transformed into dichotomous. Coded 1 for not active physical activity, coded o for active physical activity.

Diet was defined as a statement of the subject to the behavior in taking the nutrition therapy by medical personnel whether it is in accordance with the type, number and schedule of meals recommended in DM patient self-care management. The measurement scale was continuous, but for the purpose of data analysis, it was transformed into dichotomous. Coded 1 for uncontrolled diet, coded o for controlled diet.

Treatment obedience was defined as the subject's statement on the behavior in receiving treatment therapy provided by a healthcare provider consisting of drugrelated constraints, barriers about the health care system, deliberate obstacles by the subject and inadvertent obstacles by the subject as measured using a questionnaire from ABQ (Adherense Barriers Questionnaire) (Muller et al., 2015). The measure- 
Indonesian Journal of Medicine (2018), 3(1): 1-13 https://doi.org/10.26911/theijmed.2018.03.01.01

ment scale was continous, but for the purpose of data analysis, it was transformed into dichotomous. Coded 1 for not obedient, coded o for obedient.

Health cost was defined as the amount of costs/ money used for treatment based on the participation of patients on health insurance related to the health funding sources needed to utilize health care and treatment efforts. Measurement of health financing is based on the participation of DM type 2 patients in health insurance either managed by the government or by the private sector. Blood samples are the result of laboratory examination of DM type 2 subjects to blood samples which become the benchmark of health status and were done routinely every 3 months. Blood samples include: HbA1c, Blood Sugar at a Time (GDS), Blood Sugar 2 Hours after eating, Cholesterol, Trigliseride, LDL, HDL, Hb\% and Creatinine Serum. The measurements were based on laboratory results that have been standardized by the National Glycohaemoglobin Standarization Program (NGSP) and measurements of secondary data on hospital medical records.

\section{Study Instruments}

The research instrument used for data collection was a questionnaire that has been tested for its validity and reliability. The validity test included content and face validity. The reliability test in was conducted on 20 patients who underwent treatment Dr. Moewardi Hospital, Surakarta, both in case population (10) and control (10). The reliability test was performed by measuring the variables using the SPSS 22 statistical program which can calculate the total-item correlation $(\geq 0.20)$ and Cronbach alpha $(\geq 0.70)$.

\section{Data Analysis}

The data analysis was conducted using multiple logistic regression analysis to determine the magnitude of the influence of determinants that affect the occurrence of macrovascular and microvascular complications of patients with type 2 diabetes.

\section{Research Ethics}

The research ethics included informed consent, anonymity, confidentiality and ethical clearance. The ethical clearance in this study was conducted in Dr. Moewardi Hospital, Surakarta.

\section{RESULTS \\ 1. Sample characteristics}

Table 1 shows that the average of BMI in case group (mean $=24.84 ; \mathrm{SD}=4.28$ ) was little higher than in control group (mean= 24.09; $\mathrm{SD}=3.30$ ). The average of systolic blood pressure in case group (mean= 138.37; $\mathrm{SD}=26.22$ ) was higher than in control group (mean $=134.67 ; \mathrm{SD}=20.55)$.

The control group mostly had good quality of life with 63 samples (84\%) and in the case group mostly with poor quality of life of 86 samples (57.3\%). In the case group (mean $=320.31 ; \mathrm{SD}=108.71)$ had longer duration of illness than control group (mean= 251.47; $\mathrm{SD}=81.10$ ).

The number of patients with depression was higher in case group (119 patients, 79.4\%) than control group (44 patients, 58.6\%). Active physical activity was higher in control group (6o patients, $80 \%$ ) than in case group (61 patients, 40.6\%).

The control group with controlled diet consisted of 51 samples (68\%) and in the case group with uncontrolled diet, there were 85 samples $(56.7 \%)$. The treatment obedience variables showed that most of the control group adhered to the treatment of 63 samples (84\%) and in the case group were largely disobedient in the treatment of 94 samples (62.7\%). Health financing/ cost variables indicated that most health insurance had 55 samples (73.3\%) in the control group and the case group, those who did not have health insurance were 76 samples (50.7\%). The variable of blood sample (hae- 
matology) got result that mostly in control group, there were 64 sample $(85.3 \%)$ controlled blood sample and in case group, there were 76 samples (50.7\%) of uncontrolled blood sample.

Table 1. The Characteristics of Samples

\begin{tabular}{|c|c|c|c|}
\hline \multirow{2}{*}{ Variable } & \multicolumn{2}{|c|}{ Status } & \multirow[b]{2}{*}{$\begin{array}{c}\text { Total } \\
\mathbf{n}=\mathbf{2 2 5}\end{array}$} \\
\hline & $\begin{array}{c}\text { Control } \\
\mathbf{n}=75\end{array}$ & $\begin{array}{c}\text { Case } \\
n=150\end{array}$ & \\
\hline Body Mass Index $\left(\mathrm{Kg} / \mathrm{m}^{2}\right)$ & $24.09 \pm 3.30$ & $24.84 \pm 4.28$ & $24.59 \pm 3.99$ \\
\hline Blood Pressure (mmHg) & $134.67 \pm 20.55$ & $138.37 \pm 26.22$ & $137.13 \pm 24.49$ \\
\hline \multicolumn{4}{|l|}{ Quality of Life } \\
\hline Good & $63(84 \%)$ & $64(42.7 \%)$ & $127(56.4 \%)$ \\
\hline $\mathrm{Bad}$ & $12(16 \%)$ & $86(57.3 \%)$ & $98(43.6 \%)$ \\
\hline Duration of Illness (Week) & $251.47 \pm 81.10$ & $320.31 \pm 108.71$ & $297 \cdot 36 \pm 105 \cdot 32$ \\
\hline \multicolumn{4}{|l|}{ Depression } \\
\hline Not Depressed & $44(58,6 \%)$ & $31(20.6 \%)$ & $75(33.3 \%)$ \\
\hline Depressed & $31(41,4 \%)$ & $119(79.4 \%)$ & $150(66.7 \%)$ \\
\hline \multicolumn{4}{|l|}{ Physical Activity } \\
\hline Active & $60(80 \%)$ & $61(40.6 \%)$ & $121(53.7 \%)$ \\
\hline Not Active & $15(20 \%)$ & $89(59.4 \%)$ & $104(46.3 \%)$ \\
\hline \multicolumn{4}{|l|}{ Diet } \\
\hline Controlled Diet & $51(68 \%)$ & $65(43.3 \%)$ & $116(51.6 \%)$ \\
\hline Uncontrolled Diet & $24(32 \%)$ & $85(56.7 \%)$ & $109(48.4 \%)$ \\
\hline \multicolumn{4}{|l|}{ Treatment Obedience } \\
\hline Obedient & $63(84 \%)$ & $56(37.3 \%)$ & $119(52.9 \%)$ \\
\hline Not Obedient & $12(16 \%)$ & $94(62.7 \%)$ & $106(47.1 \%)$ \\
\hline \multicolumn{4}{|l|}{ Health Financing/Cost } \\
\hline With health insurance & $55(73,3 \%)$ & $74(49.3 \%)$ & $129(5 \cdot 3 \%)$ \\
\hline No health insurance & $20(26,7 \%)$ & $76(50.7 \%)$ & $96(42.7 \%)$ \\
\hline \multicolumn{4}{|l|}{ Blood Samples } \\
\hline Controlled blood samples & $64(85,3 \%)$ & $74(49.3 \%)$ & $138(61.3 \%)$ \\
\hline Uncontrolled blood samples & $11(14.7 \%)$ & $76(50.7 \%)$ & $87(38.7 \%)$ \\
\hline
\end{tabular}

\section{Bivariate Analysis}

The bivariate analysis was conducted using chi-square test and Odds Ratio (OR). Table 2 shows that there was a positive relationship between BMI, blood pressure, quality of life, depression, duration of illness, physical activity, diet, medication adherence, health financing, blood sample, and macrovascular and microvascular complications in patients DM type 2.

Type 2 diabetes patients with poor quality of life had higher risk of macrovascular and microvascular complications than patients with type 2 diabetes with good quality of life $(\mathrm{OR}=3.76 ; 95 \% \mathrm{CI}=1.28$ to
11.00; $\mathrm{p}=0.015)$. Type 2 diabetes mellitus with a duration of illness $\geq 5$ years have a risk for macrovascular and microvascular complications 3.41 times than patients with type 2 diabetes mellitus $<5$ years $(\mathrm{OR}=$ $3.41 ; 95 \% \mathrm{CI}=1.16$ to $10.01 ; \mathrm{p}=0.025$ ).

Table 3 showed that type 2 DM patients with depression have a risk for macrovascular and microvascular complications 12.48 times than non-depressed type $2 \mathrm{DM}$ patients $(\mathrm{OR}=12.48$; 95\% $\mathrm{CI}=$ 2.99 to $52.05 ; \mathrm{p}=0.001$ ). 
Indonesian Journal of Medicine (2018), 3(1): 1-13

https://doi.org/10.26911/theijmed.2018.03.01.01

Table 2. Bivariate Analysis

\begin{tabular}{|c|c|c|c|c|c|c|c|c|c|}
\hline \multirow{3}{*}{ Variable } & \multicolumn{4}{|c|}{$\begin{array}{c}\text { The Status of DM } \\
\text { Tipe } 2\end{array}$} & \multirow{2}{*}{\multicolumn{2}{|c|}{ Total }} & \multirow{3}{*}{$\mathbf{O R}$} & \multirow{3}{*}{$95 \% \mathrm{CI}$} & \multirow{3}{*}{$\mathbf{p}$} \\
\hline & \multicolumn{2}{|c|}{ Control } & \multicolumn{2}{|c|}{ Case } & & & & & \\
\hline & $\mathbf{N}$ & $\%$ & $\mathbf{n}$ & $\%$ & $\mathbf{n}$ & $\%$ & & & \\
\hline \multicolumn{10}{|l|}{ BMI $\left(\mathrm{kg} / \mathrm{m}^{2}\right)$} \\
\hline Normal & 61 & 73.5 & 22 & 26.5 & 83 & 100 & $25 \cdot 35$ & $12.14-52.93$ & $<0.001$ \\
\hline Not normal & 14 & 9.9 & 128 & 90.1 & 142 & 100 & & & \\
\hline \multicolumn{10}{|l|}{$\begin{array}{l}\text { Blood Pressure } \\
\text { (mmHg) }\end{array}$} \\
\hline Normal & 53 & 41.7 & 74 & 58.3 & 127 & 100 & 2.47 & $1.37-4.46$ & 0.002 \\
\hline Not normal & 22 & 22.4 & 76 & 77.6 & 98 & 100 & & & \\
\hline \multicolumn{10}{|l|}{ Quality of Life } \\
\hline Good & 63 & 49.6 & 64 & 50.4 & 127 & 100 & 7.05 & $3.51-14.16$ & $<0.001$ \\
\hline Bad & 12 & 12.2 & 86 & 87.8 & 98 & 100 & & & \\
\hline \multicolumn{10}{|l|}{ Depression } \\
\hline Not depressed & 44 & 58.7 & 31 & 41.3 & 75 & 100 & $5 \cdot 44$ & $2.97-9.98$ & $<0.001$ \\
\hline Depressed & 31 & 20.7 & 119 & 79.3 & 150 & 100 & & & \\
\hline \multicolumn{10}{|l|}{$\begin{array}{l}\text { Duration of Illness } \\
\text { (Week) }\end{array}$} \\
\hline$<5$ years & 28 & 52.8 & 25 & 47.2 & 53 & 100 & 2.97 & $1.57-5.62$ & 0.001 \\
\hline$\geq 5$ years & 47 & 27.3 & 125 & 72.7 & 172 & 100 & & & \\
\hline \multicolumn{10}{|l|}{ Physical Activity } \\
\hline Active & 60 & 49.6 & 61 & 50.4 & 121 & 100 & 5.83 & $3.03-11.21$ & $<0.001$ \\
\hline Not Active & 15 & 14.4 & 89 & 85.6 & 104 & 100 & & & \\
\hline \multicolumn{10}{|l|}{ Diet } \\
\hline Controlled diet & 51 & 44.0 & 65 & 56.0 & 116 & 100 & 2.77 & $1.55-4.97$ & $<0.001$ \\
\hline Uncontrolled diet & 24 & 22.0 & 85 & 78.0 & 109 & 100 & & & \\
\hline \multicolumn{10}{|l|}{ Treatment Obedience } \\
\hline Obedient & 63 & 52.9 & 56 & 47.1 & 119 & 100 & 8.81 & $4 \cdot 37-17 \cdot 75$ & $<0.001$ \\
\hline Not Obedient & 12 & 11.3 & 94 & 88.7 & 106 & 100 & & & \\
\hline \multicolumn{10}{|l|}{ Health Financing/ Cost } \\
\hline With health insurance & 55 & 42.6 & 74 & 57.4 & 129 & 100 & 2.82 & $1.54-5.16$ & 0.001 \\
\hline No health insurance & 20 & 20.8 & 76 & 79.2 & 96 & 100 & & & \\
\hline \multicolumn{10}{|l|}{ Blood Samples } \\
\hline Controlled blood samples & 64 & 46.4 & 74 & 53.6 & 138 & 100 & $5 \cdot 97$ & $2.92-12.21$ & $<0.001$ \\
\hline Uncontrolled blood samples & 11 & 12.6 & 76 & 87.4 & 87 & 100 & & & \\
\hline
\end{tabular}

Table 3. The results of multivariate analysis

\begin{tabular}{lcccc}
\hline \multirow{2}{*}{ Independent Variable } & \multirow{2}{*}{ OR } & \multicolumn{2}{c}{$\mathbf{9 5 \%}$ CI } & \multirow{2}{*}{ p } \\
\cline { 3 - 4 } & & Lower limit & Upper limit & $<0.001$ \\
Body mass index & 19.88 & 5.93 & 66.68 & 0.208 \\
Blood pressure & 2.25 & 0.63 & 8.03 & 0.015 \\
Quality of life & 3.76 & 1.28 & 11.00 & 0.025 \\
The length of illness & 3.41 & 1.16 & 10.01 & 0.001 \\
Depression & 12.48 & 2.99 & 52.05 & $<0.001$ \\
Physical activity & 7.70 & 2.51 & 23.62 & 0.006 \\
Diet & 4.42 & 1.52 & 12.80 & 0.004 \\
Medication adherence & 4.73 & 1.62 & 13.78 & 0.401 \\
Health financing & 0.57 & 0.15 & 1.11 & 0.010 \\
Blood samples & 4.07 & 1.40 & & \\
Observation score & 225 & & & \\
-2 Log likelihood & 108.77 & & & \\
Nagelkerke R & & & & \\
\hline
\end{tabular}


Type 2 DM patients with inactive physical activity have a risk for macrovascular and microvascular complications by 7.70 times compared to type $2 \mathrm{DM}$ patients with active physical activity $(\mathrm{OR}=7.70 ; 95 \% \mathrm{CI}=$ 2.51 to 23.62; $\mathrm{p}<0.001)$.

Type 2 diabetes mellitus patients with uncontrolled diet have a risk for macrovascular and microvascular complications by 4.42 times than type 2 diabetes mellitus patients who controlled their $\operatorname{diet}(\mathrm{OR}=4.42$; $95 \% \mathrm{CI}=1.52$ to $12.80 ; \mathrm{p}=0.006$ ) and type 2 DM patients with non-adherent medication have a risk for macrovascular and microvascular complications by 4.73 times than type 2 diabetes mellitus patients who have medication adherence $(\mathrm{OR}=4.73 ; 95 \% \mathrm{CI}=$ 1.62-13.78; $\mathrm{p}=0.004)$.

Type 2 DM patients with uninsured health financing have a risk for macrovascular and microvascular complications by 0.57 time than type $2 \mathrm{DM}$ patients with health financing covered by insurance $(\mathrm{OR}=0.57 ; 95 \% \mathrm{CI}=0.15$ to $2.11 ; \mathrm{p}=0.401)$. However, the relationship between health financing for macrovascular and microvascular complications in type $2 \mathrm{DM}$ patients was not statistically significant.

Patients with type 2 diabetes with uncontrolled blood samples have a risk for macrovascular and microvascular complications by 4.07 times than those of type 2 DM patients with controlled blood samples $(\mathrm{OR}=4.07 ; 95 \% \mathrm{CI}=1.40$ to $11.83 ; \mathrm{p}=$ 0.010).

Based on multivariate analysis, it can be concluded that the relationship between BMI, quality of life, depression, the length of illness, physical activity, diet, medication adherence, and blood samples on macrovascular and microvascular complications in type 2 DM patients was statistically significant.

The results of analysis also found that the score of $\mathrm{R}^{2}$ Nagelkerke was 0.758 , which mean that the eight independent variables namely BMI, quality of life, depression, the length of illness, physical activity, diet, medication adherence, and blood samples could explain the variance of macrovascular and microvascular complications in type 2 DM patients by $75.8 \%$ and the rest $24.2 \%$ was explained by other factors.

\section{DISCUSSION}

\section{The effect of BMI on the macro- vascular and microvascular com- plications in patients with type 2 DM}

The result of this study showed that there was an effect of BMI on the macrovascular and microvascular complications in patients with type 2 DM. This study was supported by Selim (2017), which stated that BMI affected the incidence of type 2 DM complications. Thomas et al. (2014) stated that a significant interaction between age, BMI and glycemic levels in relation to the risk of cardiovascular complications incidence in patients with type 2 DM. Deshpande et al (2008) added that the enhancement of BMI has consistently proven to be one of the strongest risk factors for the development of DM complications. Bays, Chapman \& Grandy (2007) also stated that the enhancement of BMI was associated with increased prevalence of DM, hypertension, and dyslipidemia.

Type 2 DM patients with abnormal BMI have excessive calorie intake. The beta cells of the pancreas gland were unable to produce enough insulin to balance the excess calorie intake. As a result, blood glucose levels would be high. Zhao et al (2017) stated that higher BMI was associated with increased insulin resistance and decreased insulin sensitivity in older people with type 2 DM. 
Indonesian Journal of Medicine (2018), 3(1): 1-13

https://doi.org/10.26911/theijmed.2018.03.01.01

\section{The effect of life quality on the ma- crovascular and microvascular complications in patients with type 2 DM}

There was an effect of the quality of life on macrovascular and microvascular complications in patients with type $2 \mathrm{DM}$. This study was supported by a study done by Derakhshanpour et al. (2015), which stated that quality of life with independent variables of DM complications showed a significant association.

Sothornwit et al. (2018) stated that pain due to ischemia, inability to walk, difficulty in treating daily hospital ulcers, and unemployment stress can be a major cause of lower quality of life among patients with diabetic foot complication problems. Alcubierre et al. (2014) stated that diabetic retinopathy (a microvascular complication) was significantly associated with a lower quality of life and quality of life was significantly affected by the severity of diabetic retinopathy. Donald et al. (2013) stated that poor glycemic complications and control independently reduced the quality of life of diabetic patients.

\section{The effect of the duration of illness on the macrovascular and micro- vascular complications in patients with type 2 DM}

The result of this study showed that there was an effect of the length of illness on the macrovascular and microvascular complications in patients with type 2 DM. This study was in accordance with a study done by Abu Al-Halaweh et al. (2017) which stated that there was a significant relationship between macrovascular and microvascular complications with the duration of diabetes. Natalie et al. (2017) stated that age at diagnosis and duration of diabetes were all independently associated with an increased risk of macrovascular complications and vice versa, and the duration of diabetes was independently associated with microvascular complications.

The result of this study was also supported by a study done by Hisni et al. (2018), which stated that most patients had type $2 \mathrm{DM}$ for $>5$ years (66.7\%) for macrovascular complications. Factor which significantly associated with complications of peripheral neuropathy, retinopathy, and diabetic foot was a longer duration of diabetes $(\mathrm{p}<0.001)$. Khawaja et al (2018) stated that duration of diabetes was the strongest predictor of neuropathy of diabetic peripheral complications, compared to patients with type $2 \mathrm{DM}$ who were less than 5 years. Patients who had a duration of diabetes for $5-11$ years $(\mathrm{OR}=5.25)$ and $\geq 12$ years $(\mathrm{OR}=16.98)$ tend to have peripheral neuropathy complications $(\mathrm{p}<$ o.001). The result of this study was in line with the idea that increased duration of type 2 DM was associated with disease progression (Sazlina et al., 2014).

\section{The effect of depression on the ma- crovascular and microvascular complications in patients with Type 2 DM}

The result of this study showed that there was an effect of depression on the macrovascular and microvascular complications in patients with type $2 \mathrm{DM}$. This study was in line with a study done by Rathmann et al. (2018) which stated that depression can worsen the glycemic control and associated to faster complications development. Pan et al. (2017) in his study stated that the incidence of depression in patients with microvascular complications (diabetic nephronpathy, diabetic retinopathy, diabetic peripheral neuropathy) was significantly higher than patients without microvascular complications.

People with type 2 DM would have higher levels of depression and were directly related to hyperglycemia. Conditions 
of hyperglycemia in a long time would be damaged in various organs. The damage to these organs was a complication of type 2 DM, therefore, it would make people with type $2 \mathrm{DM}$ to be more depressed. Zhang et al. (2015) explained that type 2 DM patients with depressive symptoms had more complications than non-depressed patients.

\section{The effect of physical activity on the macrovascular and microvas- cular complications in patients with type 2 DM.}

The result of this study showed that there was an effect of physical activity on the macrovascular and microvascular complications in patients with type 2 DM. This study was in line with a study done by Balk et al. (2015) which stated that diet and physical activity reduced risk the factors for cardiovascular disease. Blomster et al. (2013) stated that diabetic patients who reported moderate to severe activity were $15 \%$ less likely to have microvascular incidence.

Riddell and Burr (2011) stated that regular exercise lowered long-term risk for cardiovascular disease complications in people with type 2 DM. Regular physical activity can regulate blood sugar levels better and prevent the complications of DM. Fox et al (2015) stated that physical activity interventions lead to the improvement in risk factors for cardiovascular disease. Lin et al. (2010) have found that most people with risk factors such as smoking (20\%), obesity (57\%), overweight (85\%), and less physical activity (36\%) can developed microvascular complications.

\section{The effect of diet on the macro- vascular and microvascular com- plications in patients with type 2 DM}

The result of this study showed that there was an effect of diet on the macrovascular and microvascular complications in patients with type 2 DM. This study was in line with a study done by Meng et al. (2017) which stated that the risk factors for cardiovascular complications in type $2 \mathrm{DM}$, low-carb dietary interventions significantly reduced triglyceride concentrations and increased HDL cholesterol concentrations. Dietary habits were an important element of cardiovascular disease risk and individual metabolism (Elmazar et al., 2014).

Metabolic control can be considered as a basis in diabetes management and its complications. A study showed that dietary intake of olive oil in the Mediterranean region had a beneficial effect on the reduction of retinopathy development in patients with type $2 \mathrm{DM}$ (Al-Sinani et al., 2010).

The implementation of dietary modification has a beneficial clinical effect and an adequate nutritional intake in diabetic patients. On the diabetic diet, it showed lower total cholesterol, triglyceride, and AST (aspartate amino transferase) levels (Cho, Shin \& Chung, 2014).

\section{The effect of medication adherence on the macrovascular and micro- vascular complications in patients with type 2 DM}

The result of this study showed that there was an effect of medication adherence on the macrovascular and microvascular complications in patients with type $2 \mathrm{DM}$. This study was in line with a study done by Li et al (2018) which stated that poor adherence to medication $(\mathrm{AHR}=1.20 ; 95 \% \mathrm{CI}=1.06$ to 1.35) when compared togood adherence was a predictor of macrovascular complications in type $2 \mathrm{DM}$.

Sloan et al. (2004) stated that adherence and blood glucose and lipid test were often associated with reduced frequency of hospitalization in DM patients, including for vascular and kidney complications. Polonsky and Henry (2016) stated that poor adherence was associated with inadequate glycemic control, increased use of health 
Indonesian Journal of Medicine (2018), 3(1): 1-13 https://doi.org/10.26911/theijmed.2018.03.01.01

care resources, higher medical costs, and higher mortality rates.

\section{The effect of blood samples on the macrovascular and microvascular complications in patients with Type 2 DM}

The result of this study showed that there was an effect of blood samples on the macrovascular and microvascular complications in patients with type $2 \mathrm{DM}$. This study was supported by a study done by Khanam et al (2017) which stated that the average with standard deviation (SD), age, systole blood pressure, diastolic blood pressure, HbA1c, fasting blood sugar, blood sugar 2 hours after meals, and serum creatinine were found to have significantly higher risk for complications compared to the subjects who did not have complications. The result of this study also showed that duration levels of diabetes and $\mathrm{Hb} \%$ were significantly more in those who did not have complications compared to subjects with complications.

The result of this study was also in line with a study by $\mathrm{Abu} \mathrm{Al-Halaweh} \mathrm{et} \mathrm{al}$ (2017), which stated that the average of HbA1c for patients with microvascular disease was $9.99 \%(\mathrm{SD}=2.12)$ compared to 8.89\% ( $\mathrm{SD}=1.93, \mathrm{p}<0.001)$ for those without microvascular complications. The average of HbA1c for patients with macrovascular disease was $9.44 \%(\mathrm{SD}=2.02)$ compared to $9.18 \%(\mathrm{SD}=2.04)$ for those without macrovascular disease $(\mathrm{p}=0.11)$.

Hisni et al. (2018) on the result of his study showed that after getting self-management support, the experimental group participants showed significant differences in fasting blood sugar, total cholesterol, HDL cholesterol, systolic blood pressure, and diastolic blood pressure before and after receiving the program, on the prevention of cardiovascular complications behavior in older people with uncontrolled type
2 DM. The result of this study was also supported by a study done by Selim (2017) which stated that blood samples of cholesterol, LDL, HDL, trigliserid affected the incidence of type $2 \mathrm{DM}$ complications retinopathy $(\mathrm{OR}=1.17 ; 95 \% \mathrm{CI}=0.73$ to 1.87, diabetic foot ulcers $(\mathrm{OR}=2.32,95 \%$ $\mathrm{CI}=1.14$ to 4.01$)$, and coronary arteries $(\mathrm{OR}=1.03 ; 95 \% \mathrm{CI}=0.64$ to 1.66$)$.

Based on the results of this study, it can be concluded that the risk of macrovascular and microvascular complications in patients with type $2 \mathrm{DM}$ was the determinants of BMI, quality of life, depression, the length of illness, physical activity, diet, medication adherence, and blood sample control.

\section{REFERENCES}

$\overline{\text { Abu Al-Halaweh A, Davidovitch N, Almdal, }}$ TP, Cowan A, Khatib S, Nasser-Eddin L, Baradia Z (2017). Prevalence of type 2 diabetes mellitus complications among palestinians with T2DM. Diabetes \& Metabolic Syndrome: Clinical Research \& Reviews.https://doi.org/ 10.1016/ j.dsx.2017.05.017.

Alcubierre N, Rubinat E, Traveset A, Martinez-Alonso M, Hernandez M, Jurjo C, Mauricio D (2014). A prospective cross-sectional study on quality of life and treatment satisfaction in type 2 diabetic patients with retinopathy without other major late diabetic complications. Health and Quality of Life Outcomes, 12(1), 1-12. https:// doi.org/10.1186/s12955-014-0131-2.

Al-Kaabi J, Al-Maskari F, Afandi B, Parkar H, Nagelkerke N (2009). Physical Activity and Reported Barriers to Activity Among Type 2 Diabetic Patients in the United Arab Emirates. The Review of Diabetic Studies, 6(4), 271-278. Https://doi.org/10.1900/RDS.2009.6.271. Al-Sinani M, Min Y, Ghebremeskel K, Qa- 
zaq HS (2010). Effectiveness of and adherence to dietary and lifestyle counselling: Effect on metabolic control in Type 2 diabetic Omani patients. Sultan Qaboos Univ Med J. 10:341-9.

Balk EM, Earley A, Raman G, Avendano EA, Pittas AG, Remington PL. (2015). Combined diet and physical activity promotion programs to prevent type 2 diabetes among persons at increased risk: a systematic review for the community preventive services task force. Ann Intern Med. 163:437-451. doi: 10.7326/M15-0452.

Bays HE, Chapman RH, Grandy S (2007). The relationship of body mass index to diabetes mellitus, hypertension and dyslipidaemia: Comparison of data from two national surveys. International Journal of Clinical Practice, 61(5), 737-747. https://doi.org/10.1111/j.17421241.2007.01336.x.

Blomster J, Chow C, Zoungas S, et al. (2013). The influence of physical activity on vascular complications and mortality in patients with type 2 diabetes mellitus. Diabetes, Obesity and Metabolism. 15(11):1008-1012.

Cho Y, Shin M, Chung H. (2014). Effects of Diet Modification on Meal Quality and Quality of Life in Korean Diabetic Patients: Data from Korea National Health and Nutrition Examination Survey (2007-2011). Clinical Nutrition Research, 3, 106-114. https://doi.org/http://dx.doi.org/10.7762/cnr.2014.3 .2.106.

Cohen RV, Pereira TV, Aboud CM, De Paris Caravatto PP, Petry TBZ, Correa JLL, Le RC (2017). Microvascular Outcomes after Metabolic Surgery (MOMS) in patients with type 2 diabetes mellitus and class I obesity: Rationale and design for a randomised controlled trial. BMJ
Open, 7(1). https://doi.org/10.1136/bmjopen-2016-013574.

Dinas Kesehatan Provinsi Jawa Tengah. (2015). Profil Kesehatan Provinsi Jawa Tengah. Dinas Kesehatan Provinsi Jawa Tengah, 48-49. Retrieved from dinkesjatengprov.go.id/v2015/dokume n/profil2015/Profil_2015_fix.pdf.

Derakhshanpour F, Vakili MA, Farsinia M, \& Mirkarimi K. (2015). Depression and Quality of Life in Patients With Type 2 Diabetes. Iranian Red Crescent Medical Journal, 17(5). https://doi.org/10.5812/ircmj.17(5)2015.27676.

Deshpande AD, Harris-Hayes M, Schootman M (2008). Epidemiology Of Diabetes and Diabetes-Related Complications. Phys Ther. 88: 1254-1264.

Donald M, Dower J, Coll JR, Baker P, Mukandi B, \& Doi SAR. (2013). Mental health issues decrease diabetes-specific quality of life independent of glycaemic control and complications: Findings from Australia's living with diabetes cohort study. Health and Quality of Life Outcomes, 11(1), 1. https://doi.org/10.1186/1477-7525-11-170

Elmazar HM, Essa AB, Ojurongbe O, Oyesiji K, Ojo J, Odewale G, et al. (2014). Environmental and dietary factors affecting the progression of Type 2 diabetic retinopathy in Aljabal Algharby, Libya. Int Res J Med Med Sci. 2:1-5.

Fox CS, Golden SH, Anderson C, Bray GA, Burke LE, De Boer IH, Vafiadis DK. (2015). Update on prevention of cardiovascular disease in adults with type 2 diabetes mellitus in light of recent evidence: A scientific statement from the American Heart Association and the American diabetes association. Diabetes Care, 38(9), 1777-1803. https://doi.org/10.2337/dci15-0012.

Hisni D, Rukmaini R, Saryono S, Chinnawong $\mathrm{T}$, Thaniwattananon $\mathrm{P}$ (2018). 
Cardiovascular self-management support program for preventing cardiovascular complication behaviors and clinical outcomes in the elderly with poorly controlled type 2 diabetes mellitus in Indonesia: A pilot study. Japan Journal of Nursing Science, 1-12. https://doi.org/10.1111/jjns.12208

IDF. (2015). IDF Diabetes Atlas. International Diabetes Federation. https://doi.org/10.1289/image.ehp.v119.io3.

Khanam PA, Hoque S, Begum T, Habib SH, Latif ZA (2017). BIRDEM General Hospital Dhaka, Bangladesh 122 , Kazi Nazrul Islam Avenue. Diabetes \& Metabolic Syndrome: Clinical Research \& Reviews.ttps://doi.org/10.1016/j.dsx.2017.04.007.

Khawaja N, Abu-Shennar J, Saleh M, Dahbour SS, Khader YS, Ajlouni KM (2018). The prevalence and risk factors of peripheral neuropathy among patients with type 2 diabetes mellitus; the case of Jordan. Diabetology \& Metabolic Syndrome, 10(1), 8. https://doi.org/10.1186/s13098-018-0309-6.

Li PI, Wang JN, \& Guo HR. (2018). A longterm quality-of-care score for predicting the occurrence of macrovascular diseases in patients with type 2 diabetes mellitus. Diabetes Research and Clinical Practice. https://doi.org/10.1016/j.diabres.2018.02.027.

Lin EH, Rutter CM, Katon W, Heckbert S $\mathrm{R}$, Ciechanowski P, Oliver MM et al. (2010). Depression and advanced complications of diabetes. a propective cohort study. Diabetes Care. 33(2):264-9.

Ma RC. (2016). Genetics of cardiovascular and renal complications in diabetes. Journal of Diabetes Investigation, 7(2), 139-154. https://doi.org/10.1111/jdi12391.

Meng Y, Bai H, Wang S, Li Z, Wang Q,
Chen L (2017). Efficacy of low carbohydrate diet for type 2 diabetes mellitus management: A systematic review and meta-analysis of randomized controlled trials. Diabetes Res Clin Pract. 131:124-131. doi: 10.1016/j.diabres.2017.07.006.

Murti B. (2016). Prinsip Dan Metode Riset Epidemiologi. Surakarta: Program Studi Ilmu Kesehatan Masyarakat, Program Pascasarjana, Universitas Sebelas Maret.

Müller S, Kohlmann T, \& Wilke T. (2015). Validation of the Adherence Barriers Questionnaire - An instrument for identifying potential risk factors associated with medication-related nonadherence Quality, performance, safety and outcomes. BMC Health Services Research, 15(1). https://doi.org/10.1186/s12913-015-0809-0.

Natalie N, Sanjeeva R, Adelle G, Stephane $H$, Jeff RF, Natalie W, Jencia W, Sophia Z (2017). Age, age at diagnosis and diabetes duration are all associated with vascular complications in type 2 diabetes. Diabetes and its complications journal. doi:10.1016/j.jdiacomp.2017.11.009.

Pan S, Liu ZW, Shi S, Ma X, Song WQ, Guan GC, LV Y. (2017). Hamilton rating scale for depression-24 (HAMD24) as a novel predictor for diabetic microvascular complications in type 2 diabetes mellitus patients. Psychiatry Research, 258, 177-183. https://doi.org/10.1016/j.psychres.2017.07.050.

Polonsky WH, Henry RR (2016). Poor medication adherence in type 2 diabetes: Recognizing the scope of the problem and its key contributors. Patient Preference and Adherence, 10, 1299-1306. https://doi.org/10.2147/PPA.S106821.

Rathmann W, Scheerer M, Rohwedder K, 
Busch S, Kostev K (2018). Changes in patient characteristics, glucose lowering treatment, glycemic control and complications in type 2 diabetes in general practices (Disease Analyzer, Germany: 2008-2016). Postgraduate Medicine, 130(2), 244-250. https://doi.org/10.1080/00325481.2018.1421 842.

Riddell MC, Burr J (2011). Evidence-based risk assessment and recommendations for physical activity clearance: diabetes mellitus and related comorbidities. This paper is one of a selection of papers published in this Special Issue, entitled Evidence-based risk assessment and recommendations for physical activity clearance, and has undergone the Journal's usual peer review process. Applied Physiology, Nutrition, and Metabolism, 36(S1), S154-S189. https://doi.org/10.1139/h11-063

Sazlina SG, Browning C, \& Yasin S. (2013). Interventions to Promote Physical Activity in Older People with Type 2 Diabetes Mellitus: A Systematic Review. Frontiers in Public Health, 1 (December), 1-13. https://doi.org/10.3389/fpubh.2013.00071.

Selim S (2017). Frequency and pattern of chronic complications of diabetes and their association with glycemic control among adults with type 2 diabetes in Bangladesh. Diabetes and Metabolic Syndrome: Clinical Research and Reviews, 11, S329-S332. https://doi.org/10.1016/j.dsx.2017.03.010.
Sloan FA, Bethel MA, Lee PP, Brown DS, Feinglos $\mathrm{MN}$ (2004). Adherence to guidelines and its effects on hospitalizations with complications of type 2 diabetes. Rev Diabet Stu1:29-38.

Sothornwit J, Srisawasdi G, Suwannakin A., Sriwijitkamol A. (2018). Decreased health-related quality of life in patients with diabetic foot problems. Diabetes, Metabolic Syndrome and Obesity: Targets and Therapy. (11): 35-43. https://doi.org/10.2147/DMSO.S154304.

Thomas G, Khunti K, Curcin V, Molokhia M, Millett C, Majeed A, Paul S (2014). Obesity paradox in people newly diagnosed with type 2 diabetes with and without prior cardiovascular disease. Diabetes, Obesity and Metabolism, 16(4), 317-325. https://doi.org/10.1111/dom.12217

Zhang W, Xu H, Zhao S, Yin S, Wang X, Guo J, Tian D (2015). Prevalence and influencing factors of co-morbid depression in patients with type 2 diabetes mellitus: a General Hospital based study. Diabetology \& Metabolic Syndrome, 7(1), 6o. https://doi.org/10.1186/s13098-015-0053-0.

Zhao Q, Laukkanen J, Li Q, Li G (2017). Body mass index is associated with type 2 diabetes mellitus in Chinese elderly. Clinical Interventions in Aging, Volume 12, 745-752. https://doi.org/10.2147/CIA.S130014 